\title{
The Effect of Carrying out Writing to Learn Activities on Academic Success of Fifth Grade Students in Secondary School on the Subject of "Force and Motion"
}

\author{
Sabriye Seven ${ }^{1}$, Asiye Pinar Koksal ${ }^{2}$, Gulsen Kocak ${ }^{1, *}$ \\ ${ }^{1}$ School of Science Education, Kazim Karabekir Education Faculty, Ataturk University, Turkey \\ ${ }^{2}$ Center of Science and Art, Turkey
}

Copyright $@ 2017$ by authors, all rights reserved. Authors agree that this article remains permanently open access under the terms of the Creative Commons Attribution License 4.0 International License

\begin{abstract}
The aim of this study is to investigate the impact of writing poems and keeping a journal as writing-to-learn activities on the academic achievement of students in teaching the Force and Motion unit in the Science class of fifth grade students in secondary school. Sample of the study consists of 50 students who study in the fifth grade of two different secondary schools located in the east of Turkey in the school year of 2012-2013. These students were assigned objectively to the groups EG1, which performed the activity of writing poems, EG2, which performed the activity of keeping journal, and CG, to which conventional method was applied. That is to say, the experiment and control groups are informed about homogeneity in terms of preliminary knowledge, interest and skill. The study is a quasi-experimental study, where academic achievement test consisting of 25 multiple-choice questions was applied as pretest-posttest. The data were analyzed statistically using SPSS 15. As a result of findings of study, a significant difference was found in terms of academic achievement between EG1, which wrote poems, and CG, to which conventional method was applied. However, no significant difference between EG2, which kept journal, and CG, to which conventional method was applied. In this study, it was concluded that writing poems in the Force and Motion unit has statistically significant impact on academic achievement of fifth grade students, but keeping journal has no statistically significant impact on academic achievement.
\end{abstract}

Keywords Writing-to-Learn Activity, Academic Achievement, Scientific Literacy

\section{Introduction}

Science is defined as the efforts to systematically investigate the observed nature and natural phenomena and estimate events that have not yet been observed (Cepni, 2008) [7]. In school programs, science lessons are generally included for three purposes: 1- To provide scientific literacy. 2- To bring in mental and hand skills through science classes. 3- To establish a basis for vocational education in the fields of science or technology (Kaptan \& Korkmaz, 2001) [16]. In this context, one of the main purposes of science class curriculum is to ensure development of science literature individuals. These individuals have qualities such as effective decision making, research-questioning, problem solving, effective communication, research-questioning, problem-solving, and effective communication (MEB, 2013) [19]. Scientific literacy is, in general, a combination of science-related skills, attitudes, values, understandings and knowledge that are required for individuals to develop research-questioning, critical thinking, problem-solving and decision-making skills, become life-long learning individuals, and sustain their sense of curiosity about their environment and the world (MEB, 2005) [20].UNESCO (1994) [23], states that science and technology literacy is a requirement of modern life. Scientific literacy is to know important science concepts, theories, laws and scientific research methods; understand the effects of science, technology and society on each other and the relations among them; be able to use theoretically taught knowledge in problem solving in daily life, explaining science-related social problems and decision making; be able to write, read and understand scientific articles, journals and books; be able to take part in science discussions, express one's own ideas, interpret what is told; and have necessary knowledge and ability for objective, critical and creative thinking (Cepni, Ayvacı \& Bacanak, 2006, p. 45) [6].

The general objectives of science literacy can be listed as follows (Gucluer, 2012) [11]:

- Becoming familiar with the natural world and recognizing its diversity and unity.

- Understanding key concepts and principles of science. 
- Being aware of certain important links that connect science, mathematics, and technology.

- Understanding that science, mathematics and technology are the product of human efforts; and recognizing the strengths and limitations that it brings to those areas.

- Having have scientific thinking capacity.

- Using science knowledge and ways of scientific thinking for individual and social purposes.

Writing that supports scientific literacy has attracted the attention of scientists in the fields of linguistics, psychology and literature for the last 50 years (Gunel, Kabatas-Memis, Buyukkasap, 2009) [13]. Especially between 1960 and 1970, the integration of education and writing and the application of it in all subject areas were greatly encouraged by educators and researchers (Britton, Burgess, Martin, McLeod \& Rosen, 1975; Bangert-Drowns, Hurley \& Wilkinson, 2004) [5], [2]. Writing is one of the most frequently used educational activities in ensuring critical thinking of students, the structuring of new knowledge and the advancement of learning (DeNight, 1992; Klein, 1999) [10], [17].

Among the benefits of writing, the benefit of preserving the subject content and making the subject understandable holds an important place (Bangert-Drowns, Hurley \& Wilkinson, 2004) [2]. It also encourages students to develop metacognitive skills and to think about learning strategies (Brewster, C. \& Klump, J. (2004) [4]. The act of writing deepens understanding of the content of subject, develops critical thinking, collaborative learning and communication skills; reinforces having command of science, concepts and principles; and also contributes to other elements of communication such as reading, speaking and listening (Chatel, 1997) [9]. Writing requires the active organization of personal understandings (Bangert-Drowns, Hurley \& Wilkinson, 2004) [2].Thus, the act of writing forces writer to write his feelings more clearly (Yıldız \& Buyukkasap, 2011) [25].
The above-mentioned act of writing is a writing-to-learn activity such as writing letter, preparing brochure, preparing poster, writing poems, creating concept map and keeping journal that is not traditional writing but facilitates critical thinking and conceptual change (Klein, 1999; Tynjala, 1998; Mason \& Boscolo, 2000) [17], [22], [18]. Beretier and Scardamalia (1987) [3] suggested the models of knowledge-telling and knowledge-transforming in relation to writing-to-learn activity. In knowledge-telling model, students choose a topic systematically, recall understandings, a draft is prepared, mistakes are corrected and final copy is prepared. In such type of writing, the process is linear and away from socio-cultural interaction. According to this model, achievement of an individual depends on the amount of knowledge he stores in his memory. On the other hand, knowledge-transforming model encourages educators in cases such as setting goals, identifying readers, thinking, negotiating, strategic planning, review and reflection. Knowledge-transforming is mediated by an active problem solving (Beretier \& Scardamalia, 1987; Yore, Hand \& Prain, 1999) [3], [26].

Yore, Hand \& Prain, (1999) [26] list some of the requirements in writing class as follows:

- Writing is used to promote learning.

- Student and professor interact during the writing process.

- Writing plays a major role in course grades.

- Students produce a minimum of 4,000 words of text.

- Class enrollment is limited to 20 students.

In subsequent studies, writing-to-learn as an area of content has been categorized in two, namely expressive writing and product-oriented writing. Expressive writing allows for students to investigate their personal thoughts without concern for compromise, while product-oriented writing is more formal and requires attention for literacy image (Chatel \& Lord, 1998; Sorensen, 1998) [8], [21]. The table gives some examples of these two writing-to-learn categories.

Table 1. Expressive and Product-Oriented Writing Table

\begin{tabular}{|l|l|}
\hline Expressive Writing & Product-Oriented Writing \\
\hline * Writing to reach primary information & Essays \\
Free Writing & Research Reports \\
Brainstorming & Laboratory Reports \\
Concept Map & Book Reports \\
Problem Analysis & Persuasive Dialogues \\
*Writing to express claims & Editorial \\
Keeping journal & Letter to the Editor \\
Taking notes & Speaking \\
Keeping diary & Movie, documentary and book criticism \\
Summaries & News Reports \\
Peer dialogues & Newspaper Articles \\
Lecture notes & Advertisements \\
\hline
\end{tabular}

* This model was adapted from expressive writing and product-oriented writing tables of Chatel and Lord (1998)[8] as writing-to-learn model. 
The purpose of this study is to investigate how the use of poems and journal by students as non-traditional types of writing affects their learning of Force and Motion unit in the science class and how students see the process from their perspective. In this context, research question is as follows:

- How does writing poems and keeping journal as writing-to-learn activities affect the learning of "Force and Motion” unit by students?

\section{Method}

\subsection{Research Model}

The study is a quasi-experimental study and was conducted with 50 fifth grade students of a secondary school located in the east of Turkey. The impact of act of writing poems on academic achievement was examined in one of the experimental groups (EG1). In another experimental group (EG2), the impact of act of keeping journal on academic achievement was investigated. In the control group (CG), the impact of traditional method on academic achievement was examined.

\subsection{Study Group}

Sample of the study consists of 50 students who study in the fifth grade of two different secondary schools located in the east of Turkey in the school year of 2012-2013. The number of girls and boys of these students is like the following table 2 . The students were divided into a control group and two experimental groups with unbiased assignment method. That is to say, the experiment and control groups are informed about homogeneity in terms of preliminary knowledge, interest and skill. These students were assigned objectively to the groups EG1, which performed the activity of writing poems, EG2, which performed the activity of keeping journal, and CG, to which conventional method was applied. The study is a quasi-experimental study, where academic achievement test consisting of 25 multiple-choice questions was applied as pretest-posttest. The data were analyzed statistically using SPSS 15.

Table 2. Number of Female and Male Students in the Classes in which the Applicant Performed

\begin{tabular}{|c|c|c|c|}
\hline GROUPS & SEX & & TOTAL \\
\hline \multirow{3}{*}{ EG1 } & MALE & FEMALE & \\
\cline { 2 - 3 } EG2 & 11 & 6 & 17 \\
CG & 7 & 10 & 17 \\
TOTAL & 10 & 6 & 16 \\
\hline
\end{tabular}

\subsection{Study Process}

The sample consisted of a total of 50 students in three sections of 6th grade. The same teacher attended experimental groups and control group. The teacher used the same method and technique of teaching for all three groups. Firstly, the teacher introduced basic concepts about the subject and covered the formulas of the subject with their ways of derivation. Then the teacher ended the subject by solving many questions. All three groups took notes about what the teacher said.

Students in the experimental group were given guidelines about directives on writing poems and keeping journal. Also, they were verbally told about how to write poems and how to keep journal. Moreover, other types of writing were briefly mentioned. Course notebooks of students in the control group were also examined.

Before the study started, all students were subjected to subject-based science achievement test as pre-test and instructional time of 4 hours per week for 4 weeks was spent for the "Force and Motion" unit. The "Force and Motion" unit was covered for all groups in the study by the same teacher using the same method and technique. Upon completion of writing activities, the students were subjected to subject-based science achievement test about "Force and Motion” as post-test.

The process of application is shown in Tables 3, 4 and 5 .

Table 3. Study Plan of Experimental Group 1

\begin{tabular}{|l|l|}
\hline WEEK & \multicolumn{1}{c|}{ EXPERIMENTAL GROUPS 1 (WRITING POEMS) } \\
\hline Week 1 & Application of pre-test \\
Week 2 & Distribution of guidelines of writing poems and teaching of application \\
Week 3 & Introduction of basic concepts about Force and Motion \\
Week 4 & Covering formulas and their ways of deviation - Performing laboratory work \\
Week 5 & Solving questions - Submission of assignment about writing poems \\
Week 6 & Assessment and Feedback - Correcting and submitting the poems \\
Week 7 & Application of post-test \\
\hline
\end{tabular}


Table 4. Study Plan of Experimental Group 2

\begin{tabular}{|l|l|}
\hline WEEK & \multicolumn{1}{|c|}{ EXPERIMENTAL GROUPS 2 (KEEPING JOURNAL) } \\
\hline Week 1 & Application of pre-test \\
Week 2 & Distribution of guidelines of keeping journal and teaching of application \\
Week 3 & Introduction of basic concepts about Force and Motion \\
Week 4 & Covering formulas and their ways of deviation - Performing laboratory work \\
Week 5 & Solving questions - Submission of assignment about keeping journal \\
Week 6 & Assessment and Feedback - Correcting and submitting the journals \\
Week 7 & Application of post-test \\
\hline
\end{tabular}

Table 5. Study Plan of Control Group

\begin{tabular}{|l|l|}
\hline WEEK & \\
\hline Week 1 & CONTROL GROUP \\
Week 2 & Examination of course notebook \\
Week 3 & Introduction of basic concepts about Force and Motion \\
Week 4 & Covering formulas and their ways of deviation - Performing laboratory work \\
Week 5 & Solving questions \\
Week 6 & Checking whether what teacher told are written down \\
Week 7 & Application of post-test \\
\hline
\end{tabular}

\subsection{Data Collection Tools}

In the force and motion unit, subject-based science achievement test was used as a data collection tool. The test was applied as pre-post test at the beginning and end of study. The science achievement test includes 25 multiple-choice questions. This test was prepared by researcher using the questions asked in the exams organized by the Ministry of National Education. In order to maintain face validity of subject-based science achievement test, opinions of two instructors, research assistants and three science teachers from secondary school were received.

\subsection{Analysis of Data}

The data obtained from the study were analyzed using the SPSS 15.0 statistical software package. The following statistical methods were used to find answer to research problems.

1. "Kruskal-Wallis H Test" was used to determine whether there is a significant difference between the results of pre-tests that were applied to experimental groups where the activities of writing poems and keeping journal were used (EG1 and EG2) and the control group where traditional teaching method was applied.

2. "Mann Whitney U Test" was used to determine whether there is a significant difference between the results of post-tests that were applied to EG1, which performed the act of writing poems, and CG, to which traditional method was applied.

3. "Mann Whitney U Test" was used to determine whether there is a significant difference between the results of post-tests that were applied to EG2, which performed the act of keeping journal, and CG, to which traditional method was applied.

\section{Findings}

Research findings were found using the SPSS 15 statistical software.

\subsection{Pre-Test Findings of Force and Motion Unit}

Before the application, students in the experimental and control groups were subjected to pre-test that covers the "Force and Motion" unit in the Science Curriculum of $5^{\text {th }}$ Grade of Secondary School. Accordingly, Kruskal-Wallis H test was used to research the impact of three different methods. When Table 6 is examined, it is observed that there is no statistically significant difference between the groups at a significance level of $\mathrm{p}<0.05$.

Table 6. Pre-Test Findings

\begin{tabular}{|c|c|c|c|c|}
\hline Group & N & Mean Rank & $\chi^{2}$ & p \\
\hline EG1 & 11 & 24.50 & & \\
EG2 & 19 & 22.29 & \multirow{2}{*}{2.223} & .329 \\
\hline CG & 20 & 29.10 & & \\
\hline
\end{tabular}

\subsection{Post-Test Findings of Force and Motion Unit}

"Mann Whitney U Test” was used to determine whether there is a significant difference between the results of post-tests that were applied to EG1, which performed the act of writing poems, and CG, to which traditional method was applied. When Table 7 is examined, it is observed that there is statistically significant difference between the groups at a significance level of $\mathrm{p}<0.05$

Table 7. Post-Test Findings

\begin{tabular}{|c|c|c|c|c|c|}
\hline Group & $\mathrm{N}$ & Mean Rank & Rank Sum & $\mathrm{U}$ & $\mathrm{p}$ \\
\hline EG1 & 11 & 20.77 & 228.50 & & \multirow{2}{*}{57.500} \\
\cline { 1 - 4 } CG & 20 & 13.38 & 267.50 & & \\
\hline
\end{tabular}


“Mann Whitney U Test” was used to determine whether there is a significant difference between the results of post-tests that were applied to EG2, which performed the act of keeping journal, and CG, to which traditional method was applied. When Table 8 is examined, it is observed that there is no statistically significant difference between the groups at a significance level of $\mathrm{p}<0.05$.

Table 8. Post-Test Findings

\begin{tabular}{|c|c|c|c|c|c|}
\hline Group & $\mathrm{N}$ & $\begin{array}{c}\text { Mean } \\
\text { Rank }\end{array}$ & $\begin{array}{c}\text { Rank } \\
\text { Sum }\end{array}$ & $\mathrm{U}$ & $\mathrm{p}$ \\
\hline EG2 & 19 & 22.00 & 418.00 & \multirow{2}{*}{152.000} & .284 \\
\hline CG & 20 & 18.10 & 362.00 & & \\
\hline
\end{tabular}

\section{Discussion and Conclusion}

The aim of this study is to investigate the impact of writing poems and keeping a journal as writing-to-learn activities on the academic achievement of students in teaching the Force and Motion unit in the Science class of fifth grade students in secondary school. Research problem of the study is whether there is a difference between post-test performance of students who performed the act of writing poems and students who were subjected to traditional method and post-test performance of students who performed the act of keeping journal and students who were subjected to traditional method. At the end of study, it was found that writing poems in the Force and Motion unit has impact on academic achievement of fifth grade students but keeping journal does not have significant impact on their academic achievement. The main factor in making the poetry writing group more successful can be explained as follows; few words are used in poetry. And it means a lot. The students have tried to simplify what they understand by working hard to write poetry with their understanding. This has enabled them to think intensively and internalize their work for that work. Because writing poetry is not a simple process, it affects the development of skills such as thinking, expressing, rhyming, fluent expression, developing mental dictionaries, cooperative learning (Akyol ve Dikici, 2009) [1]. As a result of this study and other studies conducted on this subject, the use of different writing-to-learn activities by teachers in classroom environment will benefit them in many aspects. Besides these benefits, writing-to-learn activities will make positive contribution to learning of students, and develop their skills of remembering, commenting, eliminating misconceptions, reinforcing the subject, and making reasonable explanation.

The number of studies and researches conducted on the use of writing-to-learn activities in science classes has increased in the last 10 years (Gunel, Hand \&Prain, 2007) [12]. As a result of these studies, it is suggested in many studies that writing-to-learn activities make different contributions to learning and the activities of writing develop communication skills of students (Tynjala 1998; Hohenshell et al. 2004; Transfers, Uzoglu, 2010) [24]. Also, writing-to-learn activity can be considered as a means of meaningful learning, in other words making the knowledge meaningful in a way to help conceptual change of students, not just writing down the information (Mason and Boscolo, 2000; Uzoglu, 2010) [18], [24].

Considering this study and other studies conducted on the subject, the use of writing-to-learn activities by teachers will have many benefits. For example, the study conducted by Mason and Boscolo (2000)[18] revealed that students performed conceptual change easier through the writing-to-learn activity. According to Hand, Prain, Lawrence \& Yore (1999)[14], writing in science classes makes it easier for students to research different ideas, helps students in integrating their prior knowledge with new concepts or integrating different concepts with each other and thus serves to understand and think these concepts and evaluate the claims about these concepts.

The following recommendations can be made in the light of findings obtained from this study:

- 1. Studies can be conducted on the impact of writing-to-learn activities other than those used in this study on achievement of students (story, concept map, poster etc.).

- 2 . This study was conducted with fifth grade students of primary school. Other studies can be conducted with students from 6th, 6th and 8th grades and high school level.

- 3 . This study attempted to determine whether two different writing activities have impact on student achievement. Students can perform more than two writing activities and its impact can be determined on student achievement in similar studies.

- $\quad 4$. This study was conducted using the force and motion unit. Similar studies can be conducted with different units.

- 5. Similar studies can also be conducted in other classes other than science.

\section{REFERENCES}

[1] Akyol, C., \& Dikici, A.(2009). The influence of poetry teaching techniques on students' attitudes and attitudes. Elementary Education Online, 8(1), 48-56.

[2] Bangert-Drowns, R.L., Hurley, M.M., \& Wilkinson, M. (2004). The Effects of School-Based Writing-to-Learn Interventions on Academic Achievement: A Meta-Analysis. Review of Educational Research, 74(1), 29-58.

[3] Bereiter, C., \& Scardamalia, M. (1987). The Psychology of Written Composition. Hillsdale, NJ: Erlbaum.

[4] Brewster, C., \& Klump, J. (2004). Writing to learn, learning to write: Revisiting writing across the curriculum in northwest secondary schools. Portland, Oregon: Northwest Regional Educational Laboratory. 
[5] Britton, J., Burgess, T., Martin, N., McLeod, A., \& Rosen, H. (1975). The development of writing abilities, 11-18. London: Macmillan.

[6] Cepni, S., Ayvacı, H. Ş., \& Bacanak, A. (2006). Fen Egitimine Yeni Bir Bakıs.Fen Teknoloji Toplum, s. 45, Trabzon.

[7] Cepni, S. (Editor). (2008). Kuramdan uygulamaya fen ve teknoloji ogretimi. (7. Bask1). Ankara: Pegem A Publishing.

[8] Chatel, R.G. \& Lord, C. (1998). A college and urban elementary classroom collaborate in using writing to learn in science. International Reading Association 43rd Annual Convention Orlando, F.L.

[9] Chatel, R.G. (1997). Writing to Learn in Science. A Curriculum Guide.

[10] DeNight, S. (1992). Writing to Learn Activities in Writing across the Curriculum Classrooms. ERIC Digest. ED 360646 Available Online

[11] Guçluer, E. (2012). Fen ve teknoloji dersinde "vucudumuzda sistemler" unitesinde fen okuryazarlığını gelistirici etkinliklerin kullanılmasının başarıya, tutuma ve bilimsel süreç becerilerine etkisi, Yayımlanmamış Doktora Tezi, Dokuz Eylül Üniversitesi Eğitim Bilimleri Enstitüsü, İzmir.

[12] Gunel, M., Hand, B., Prain, V. (2007). Writing for learning in science: A secondary analysis of six studies. International Journal of Science and Mathematics Education5, 615-637.

[13] Gunel, M., Kabatas-Memis, E. ve Buyukkasap, E. (2009). Oğrenme amaçlı yazma aktivitelerinin ve analoji kurmanın üniversite düzeyinde mekanik konularını ogrenmeye etkisinin incelenmesi. Gazi Egitim Fakültesi Dergisi, 29(2), 401-419.

[14] Hand, B., Prain, V., Lawrence C., Yore L. D. (1999). A writing in science frameworkdesigned to enhance science literacy. International Journal Of Science And Education10, 1021- 1035

[15] Hohenshell, L., Hand; B. And Staker, J., 2004. Promoting Conceptual Understanding ofBiotechnology: Writing to a Younger Audince. The American Biology Teacher,66(5) 333-338.
[16] Kaptan, F. ve Korkmaz, H. (2001). Ilkogretimde fen bilgisi ogretimi modulu 7. Ankara.

[17] Klein. D. P. (1999). Reopening inquiry into cognitive processes in writing-to-learn. Educational Psychology Review, 11(3), 203- 270.

[18] Mason, L., Boscolo, P. (2000). Writing and conceptual change. What changes? Instructional Science 28,199-226.

[19] Milli Egitim Bakanlıg1 (MEB). (2013). Ilkogretim Kurumları (1lkokullar ve Ortaokullar) Fen BilimleriDersi (3, 4, 5, 6, 7 ve 8. Sinıflar) Oğretim Programı. Milli Egitim Bakanlıgı Talim ve Terbiye Kurulu Başkanlıgı, Ankara.

[20] Milli Egitim Bakanlıgı (MEB). (2005). İlköğretim fen ve teknoloji dersi ogretim programı. Milli Eğitim Bakanlığı, Ankara.

[21] Sorensen, S. (1998). Encouraging writing achievement: Writing across the curriculum. ERIC Digest. ED327879 91 Available Online

[22] Tynjala, P. (1998). Writing as a tool for constructive learninig: Students' learning experiencesduring an experiment. Higher Education 36, 209-230.

[23] UNESCO (1994). Project 2000+ Declaration. [Brochure] (Paris, France: UNESCO).

[24] Uzoğlu, M. (2010).Ogrenme amaçlı yazma aktivitelerinin kullanımının ilköğretim seviyesinde kuvvet ve madde ünitesini öğrenmeye etkisi. Yayınlanmamış Doktora Tezi, Atatürk Üniversitesi, Erzurum.

[25] Yıldız, A., \&Büyükkasap, E. (2011). Ogretmen adaylarının belirsizlik ilkesini anlama düzeyleri ve ogrenme amaçlı yazmanın akademik basarıya etkisi. Turk Fen Eğitimi Dergisi, 8(4), 134-148.

[26] Yore, L. D., Hand, B., \& Prain, V. (1999). Writing-to-learn science: Breakthroughs, barriers, and promises. Paper presented at the International Conference of the Association for Educating Teachers in Science, Austin, TX. 